\title{
Distinct roles of presynaptic dopamine receptors in the differential modulation of the intrinsic synapses of medium-spiny neurons in the nucleus accumbens
}

\author{
Takeo Mizuno*1,2, Claudia Schmauss ${ }^{1,2}$ and Stephen Rayport*1,2
}

Address: ${ }^{1}$ Department of Psychiatry, Columbia University, 1051 Riverside Drive, Unit 62, New York, NY 10032, USA and ${ }^{2}$ Department of Neuroscience, New York State Psychiatric Institute, 1051 Riverside Drive, Unit 62, New York, NY 10032, USA

Email: Takeo Mizuno* - tm2092@columbia.edu; Claudia Schmauss - cs581@columbia.edu; Stephen Rayport* - sgr1@columbia.edu

* Corresponding authors

Published: 19 January 2007

BMC Neuroscience 2007, 8:8 doi:10.1 I86/147|-2202-8-8
Received: 20 September 2006

Accepted: 19 January 2007

This article is available from: http://www.biomedcentral.com/l47/-2202/8/8

(c) 2007 Mizuno et al; licensee BioMed Central Ltd.

This is an Open Access article distributed under the terms of the Creative Commons Attribution License (http://creativecommons.org/licenses/by/2.0), which permits unrestricted use, distribution, and reproduction in any medium, provided the original work is properly cited.

\begin{abstract}
Background: In both schizophrenia and addiction, pathological changes in dopamine release appear to induce alterations in the circuitry of the nucleus accumbens that affect coordinated thought and motivation. Dopamine acts principally on medium-spiny GABA neurons, which comprise $95 \%$ of accumbens neurons and give rise to the majority of inhibitory synapses in the nucleus. To examine dopamine action at single medium-spiny neuron synapses, we imaged $\mathrm{Ca}^{2+}$ levels in their presynaptic varicosities in the acute brain slice using two-photon microscopy.

Results: Presynaptic $\mathrm{Ca}^{2+}$ rises were differentially modulated by dopamine. The DI/D5 selective agonist SKF8I297 was exclusively facilitatory. The D2/D3 selective agonist quinpirole was predominantly inhibitory, but in some instances it was facilitatory. Studies using D2 and D3 receptor knockout mice revealed that quinpirole inhibition was either D2 or D3 receptormediated, while facilitation was mainly D3 receptor-mediated. Subsets of varicosities responded to both DI and D2 agonists, showing that there was significant co-expression of these receptor families in single medium-spiny neurons. Neighboring presynaptic varicosities showed strikingly heterogeneous responses to DA agonists, suggesting that DA receptors may be differentially trafficked to individual varicosities on the same medium-spiny neuron axon.

Conclusion: Dopamine receptors are present on the presynaptic varicosities of medium-spiny neurons, where they potently control GABAergic synaptic transmission. While there is significant coexpression of DI and D2 family dopamine receptors in individual neurons, at the subcellular level, these receptors appear to be heterogeneously distributed, potentially explaining the considerable controversy regarding dopamine action in the striatum, and in particular the degree of dopamine receptor segregation on these neurons. Assuming that post-receptor signaling is restricted to the microdomains of medium-spiny neuron varicosities, the heterogeneous distribution of dopamine receptors on individual varicosities is likely to encode patterns in striatal information processing.
\end{abstract}




\section{Background}

Both schizophrenia and addiction are thought to involve aberrant information processing in the nucleus accumbens (nAcc), which makes up the ventral part of the striatal complex. In these disorders, changes in dopamine (DA) release apparently induce alterations in the intrinsic circuitry, affecting coordinated thought and motivation [1-3]. The cellular substrate for DA action in the striatal complex is remarkably homogeneous. Ninety-five percent of nAcc are medium-spiny GABAergic neurons (MSNs). MSNs receive extensive excitatory input from cortex, amygdala, hippocampus and thalamus, feed-forward GABAergic inhibition from a small population of fast-spiking interneurons, and excitation from large aspiny cholinergic neurons $[4,5]$. MSNs give rise to a profusion of local axon collaterals that ramify within their dendritic fields, as well as to all the efferent projections from the nucleus.

In somatic recordings from striatal MSNs, whose properties are nearly indistinguishable from those of nAcc MSNs, fast-spiking interneurons appear to be responsible for the majority of inhibitory input because they impinge on more proximal dendrites [5-7], while MSNs impinge on more distal dendrites and therefore appear deceptively weak [8-10]. Recent estimates have suggested that about two thirds of the GABAergic inputs to a given MSN are intrinsic connections from other MSNs $[9,11]$. Given both their number and probable strength, the intrinsic synapses of MSNs must have an important role in striatal information processing $[9,10,12,13]$.

Considerable interest has focused on the targets of DA action in the striatal complex [14]. MSN-to-MSN synaptic connections show potent DA modulation. Guzman et al. [11] found that the intrinsic synapses were facilitated by D1 and inhibited by D2 agonists. However, Nicola et al. [15] and Taverna et al. [16] found the opposite for D1 agonists. Such contradictory results might reflect differences in the compliments of DA receptors on different MSN axons. In fact, the hypothesis that DA receptors might be differentially trafficked in the axon of MSNs was raised by Surmeier et al. [17] some time ago. However, all studies to date have been done with postsynaptic recording techniques that do not resolve single synaptic inputs. Thus, heterogeneity in the distribution of DA receptors has yet to be addressed directly.

To approach DA modulation at the level of individual synapses requires a way to activate and monitor the synapses of a single neuron. This becomes possible by using patch pipets both to fill single MSNs with a $\mathrm{Ca}^{2+}$ indicator dye and then to stimulate them. Using this approach in combination with two-photon excitation laser scanning microscopy (2PLSM), which provides the requisite spatiotemporal resolution, we were able to monitor $\mathrm{Ca}^{2+}$ tran- sients at individual presynaptic varicosities as a proxy for synaptic action. We then used DA receptor-selective agonists and DA receptor knockout (KO) mice to elucidate the modulatory actions of DA. Our results support the hypothesis that MSNs differentially traffic DA receptors to presynaptic sites.

\section{Results \\ Medium-spiny neuron intrinsic synapses function in the slice}

Parasagittal slices were made through the striatal complex and whole cell recordings obtained from MSNs in the ventral part of the complex, or nucleus accumbens (nAcc). We isolated inhibitory connections using the glutamate antagonists CNQX $(10 \mu \mathrm{M})$ and APV $(50 \mu \mathrm{M})$. Overall 1,012 cells were recorded; of these, 253 cells had coplanar proximal axons with single or multiple hot spots of activity-dependent $\mathrm{Ca}^{2+}$ responses. Of these, 38 cells remained healthy, with reproducible $\mathrm{Ca}^{2+}$ responses such that the control and post-drug responses varied by less than $5 \%$ over the course of the experiment, making possible the acquisition of a full data set.

In preliminary experiments, we tested the synaptic function of MSN-to-MSN intrinsic synapses (see additional file 1). Since MSNs make all the projections from the striatal complex to the ventral pallidum (VP), a population of MSNs can be activated selectively by antidromic field stimulation in the VP $[11,18]$. This produced a complex IPSC, after a fixed delay of about $20 \mathrm{msec}$. Antidromic action potentials were occasionally evoked in the recorded cell (10\% of cells), suggesting that some projection axons remained intact in our slice configuration. The delayed IPSC component was completely blocked by the $\mathrm{GABA}_{\mathrm{A}}$ antagonist bicuculline, and largely recovered, indicating that the intrinsic synapses of MSNs do indeed function, and inhibit neighboring MSNs.

\section{Two-photon imaging of axonal varicosities in the slice}

We patched MSNs with pipettes containing the $\mathrm{Ca}^{2+}$ sensitive green fluorescent dye OG1 and the $\mathrm{Ca}^{2+}$ insensitive red fluorescent dye Alexa594. MSN dendrites were easily recognized by virtue of their multiple spines, in contrast to the single non-spine bearing axon. Proximal dendrites and spines filled within 5 min of achieving whole cell mode, while the axon required at least $30 \mathrm{~min}$ to fill (Figure $1 \mathrm{~A})$, presumably because of its narrower bore. The single axonal process arose from the cell body and gave rise to several local axonal branches. One axonal branch extended beyond the confines of the dendritic tree to give rise to the efferent projection. In horizontal slices ( $\mathrm{n}>$ 100 ), we never imaged axonal $\mathrm{Ca}^{2+}$ rises, while in parasagittal slices we were successful in about $25 \%$ of experiments. Apparently, local MSN axons were more likely to be intact if the projection axon extended some distance 
without being cut. With the favorable orientation of the recorded cell in the slice, up to five varicose expansions or varicosities, could be imaged simultaneously in the same focal plane. We focused on proximal varicosities located within the second order branches, where dye concentrations stabilized within $30 \mathrm{~min}$ and provided reproducible signals.

In $3 \mathrm{D}$ reconstructions of recorded cells, the mean distance from the cell body to the recorded varicosities was $63 \mu \mathrm{m}$, with a range of $34-118 \mu \mathrm{m}$. Hot spots where $\mathrm{Ca}^{2+}$ levels transiently increased with stimulation were distributed at irregular intervals along the axons and coregistered with varicose expansions - presumably synaptic varicosities identified in the Alexa 594 images. These expansions had the typical en passant appearance of presynaptic varicosities on unmyelinated axons $[19,20]$.

The major challenge in this study was recording $\mathrm{Ca}^{2+}$ signals from the small synaptic varicosities of MSNs. Generally, axonal signals are several-fold dimmer than signals in small dendritic branches [20]. While Koester and Sakmann [21] were able to record single AP-induced $\mathrm{Ca}^{2+}$ responses in the terminals of neocortical pyramidal cells, single AP-induced $\mathrm{Ca}^{2+}$ responses were undetectable in MSN varicosities, presumably because they were embedded in the noise.

To detect $\mathrm{Ca}^{2+}$ responses, we adjusted the $\mathrm{Ca}^{2+}: \mathrm{Mg}^{2+}$ ratio to $3: 0.5,2: 1$ or $2: 0$ (in $\mathrm{mM}$ ). Increasing the $\mathrm{Ca}^{2+}$ concentration (ratio 3:0.5) yielded responses that became less reliable over time, presumably due to cytotoxicity. While normal $\mathrm{Ca}^{2+}$ with reduced $\mathrm{Mg}^{2+}(2: 1)$ both enhanced the amplitude of the $\mathrm{Ca}^{2+}$ responses and maintained reliability, the zero $\mathrm{Mg}^{2+}$ ratio (2:0) further enhanced responses, without apparent detrimental effects, and was therefore used for subsequent experiments. However, adjusting the $\mathrm{Ca}^{2+}: \mathrm{Mg}^{2+}$ ratio still not provide reliable single-AP evoked $\mathrm{Ca}^{2+}$ responses, so we then moved to trains of depolarizing pulses. In a MSN with a single proximal axonal varicosity (Figure 1B), we found that AP-induced $\mathrm{Ca}^{2+}$ responses (Figure $1 \mathrm{C}$ ) increased with $\mathrm{AP}$ number. The $\mathrm{Ca}^{2+}$ response showed the characteristic fast rise and slow decay kinetics [viz. [21,22]]. The decay followed a single exponential. In three MSNs, each with one varicosity, all three varicosities showed a maximal (plateau) response with 20 pulses. Trains of 10 pulses evoked sufficiently robust $\mathrm{Ca}^{2+}$ responses that reached about $50 \%$ of the maximal level, and therefore provided the necessary dynamic range to measure both inhibitory and facilitatory effects. To minimize the contribution of the noise in the $\mathrm{Ca}^{2+}$ measurements, we integrated the $\mathrm{Ca}^{2+}$ responses (measuring the area under the curve, a.u.c.). Compared to measuring peak amplitudes, the integrated $\mathrm{Ca}^{2+}$ response showed significantly less variability.
To demonstrate reproducibility of $\mathrm{Ca}^{2+}$ responses measured in this way, we did repeated stimulation under control conditions (without DA agonists), as shown in Figure 2 . The recorded MSN is shown in a projection image with the stretch of the axonal process with a single varicosity outlined (Figure 2A). The corresponding OG1 image (Figure $2 \mathrm{~B}$ ) shows that the $\mathrm{Ca}^{2+}$ response was spatially restricted to a short stretch that corresponded to the varicosity. A spline was superimposed (red line) on the OG1 image. The laser was repeatedly directed along the spline (spline scan) to produce a temporal display of the OG1 signal in response to a train of APs (Figure 2C). There was no change in the $\mathrm{Ca}^{2+}$-insensitive Alexa594 fluorescence.

In one experiment, we measured $\mathrm{Ca}^{2+}$ responses with repeated stimulation at 10 min intervals, which showed the relative stability of responses under optimal conditions (Figure 2D). To test this further, we evoked a second, control $\mathrm{Ca}^{2+}$ response in several cells. The second response was $98.0 \pm 2.2 \%$ (mean \pm s.e.m.) of the first, control response (Figure 2E). The distribution of second $\mathrm{Ca}^{2+}$ responses did not differ significantly from the normal distribution (Shapiro-Wilk W test gave a $\mathrm{W}$ value of 0.93 , with $\mathrm{p}=0.47$, which was not significant). Nor was it skewed (skewness was 0.44 , which was less than the criterion of one standard error of 2.2). Based on this analysis, changes of $5 \%$ or greater were deemed significant. Pharmacological data were then classified as showing inhibition (response $<95 \%$ of control), no change (95-105\%), or facilitation $(>105 \%)$. Data were analyzed for modulatory actions of single agonists in experiments where $\mathrm{Ca}^{2+}$ responses were stable for at least $20 \mathrm{~min}$, and for multiple agonists in cells where $\mathrm{Ca}^{2+}$ responses were stable for 40 min. Invariably somatic action potentials triggered $\mathrm{Ca}^{2+}$ responses in all imaged varicosities, consistent with prior observations [20,21,23].

\section{DA modulation of individual MSN varicosities in wild type mice}

We used the D1/D5 selective agonist SKF81297 (1 $\mu \mathrm{M}$ ) and the D2/D3 selective agonist quinpirole $(20 \mu \mathrm{M})$ to examine DA modulation of single MSN synapses. In Figure 3, the recorded MSN was rendered into a 3Dimage, with the axon shown in red, the dendrites in blue and the scanned area outlined (Figure 3A). The corresponding OG1 image (Figure 3B) showed that the stretch of axon contained five presynaptic varicosities. The spline used for scanning is shown superimposed on the axon. The spline scan images showed that the $\mathrm{Ca}^{2+}$ responses or hot spots (Figure 3C, OG1 traces) corresponded to varicosities (Figure $3 \mathrm{C}$, Alexa594 traces). Hot spots \#2, 4 and 5 showed the representative DA response (Figure $3 \mathrm{D})$, namely inhibition with quinpirole (40-77\% of control), and facilitation with SKF81297 (116-309\%). Hot spots \#1 and 3 did 

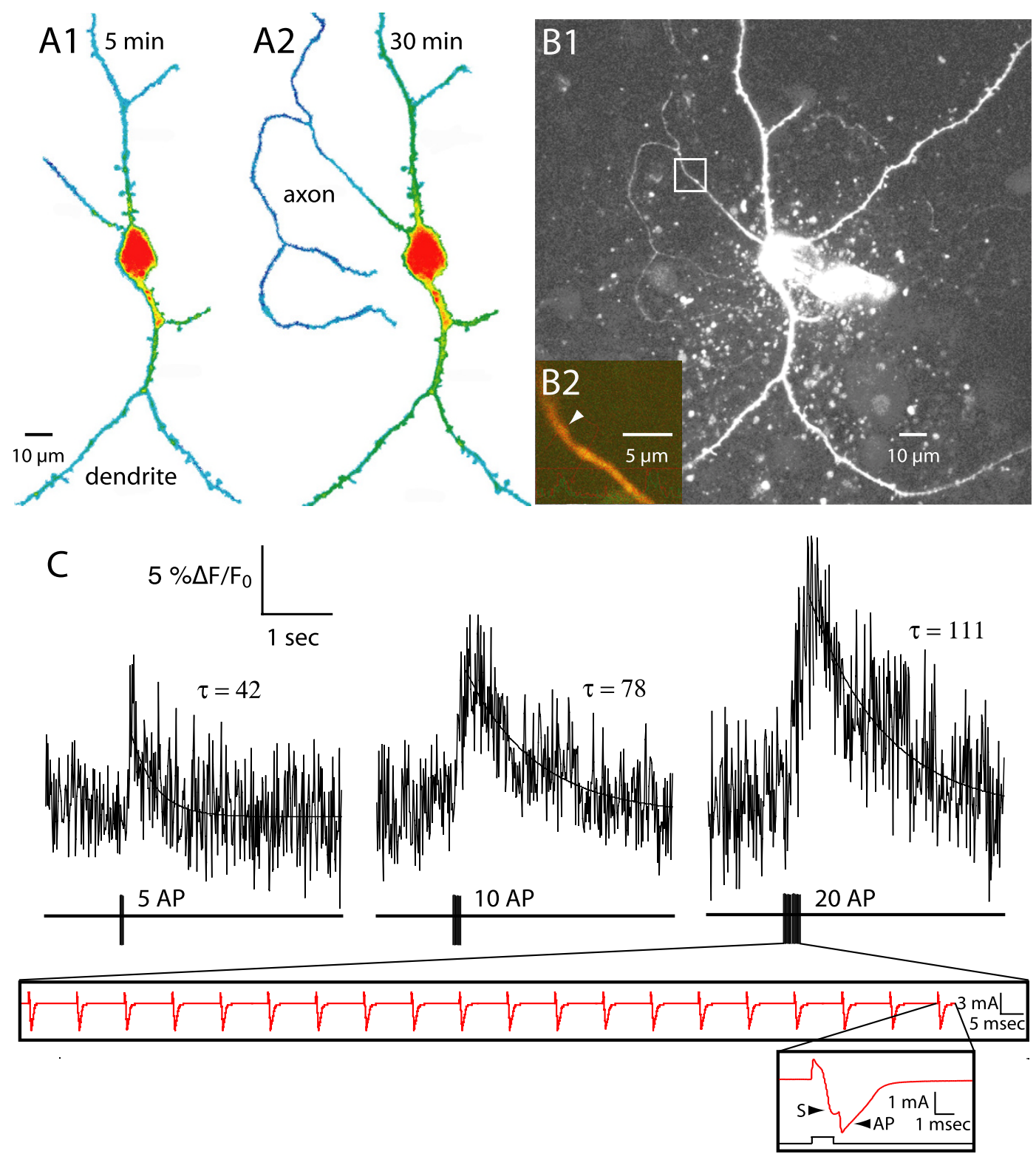

Figure I

Delayed dye diffusion identifies MSN axons. A. A single MSN was loaded with OGI and Alexa594 through the patch pipette and imaged by 2PLSM at 5 and 30 min after entering whole cell mode. Fluorescence intensity is shown in pseudocolor (Image)). Projection images (AI) were created from a z series of confocal Alexa594 images. At 5 min, the dendrites and proximal axon were filled. At 30 min (A2), dendritic labeling showed no significant change, while the axon was now clearly labeled. Dendritic processes were studded with spines, in contrast to the single axonal process, which was free of spines. B. The recorded MSN is shown in a projection image $(\mathrm{BI})$ made from the full confocal z series of Alexa594 images (50 sections at I $\mu \mathrm{m}$ intervals). The area outlined in panel BI (white rectangle) is shown enlarged in the inset (B2). This stretch of axon contained one hot spot, indicated by the arrowhead (B2). C. Presynaptic $\mathrm{Ca}^{2+}$ responses were evoked by trains of 5 , 10 or $20 \mathrm{AP}$ 's. The raw $\mathrm{Ca}^{2+}$ responses showed the typical waveform of AP-induced $\mathrm{Ca}^{2+}$ responses, with a fast rising and slow decay phase. The decay followed a single exponential curve; the decay time constant $\tau$ (in $\mathrm{msec}$ ) is indicated on each panel. Raw traces of evoked AP's are shown in the bottom panel (red trace). Note that the 20 depolarizing pulses evoked 20 AP's without failures. The last AP is shown magnified in the inset (right bottom), with the depolarizing pulse below; the end of the stimulus artifact $(\mathrm{S})$ is seen as an inflection preceding the unclamped axon spike (AP). 

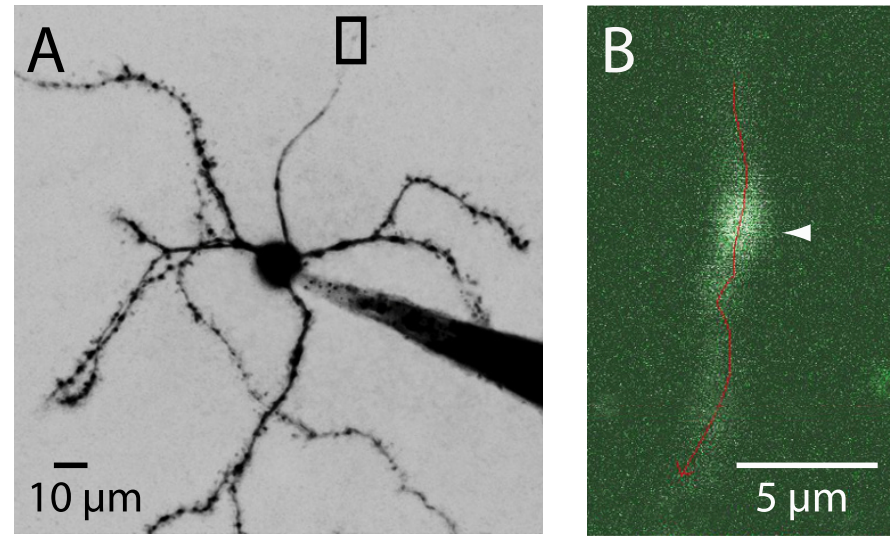

$\mathrm{D}$

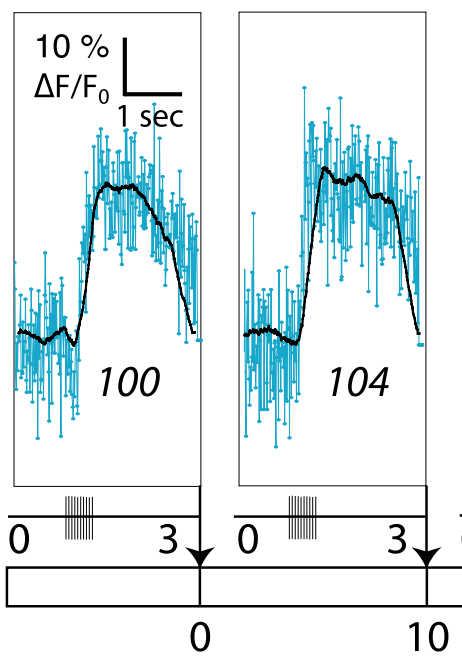

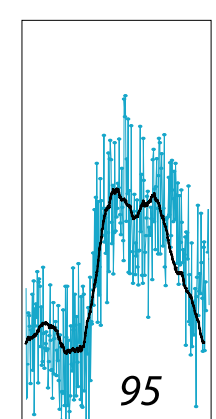

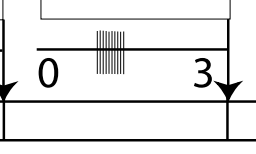

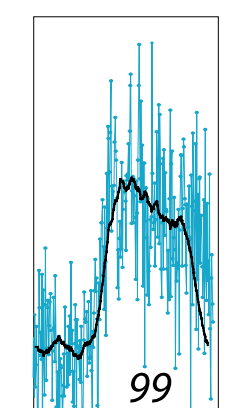

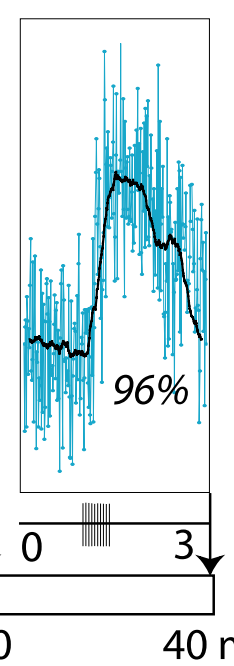

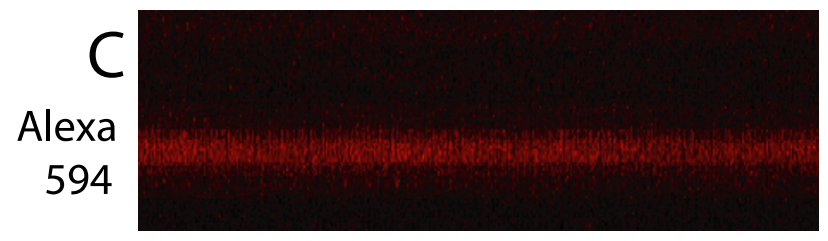

OG1

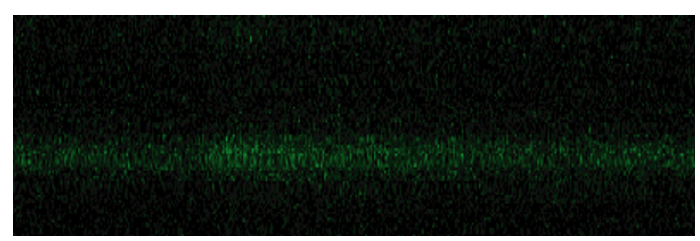

$\overline{0}$

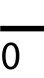

$3 \mathrm{sec}$

\section{$\mathrm{E}$}

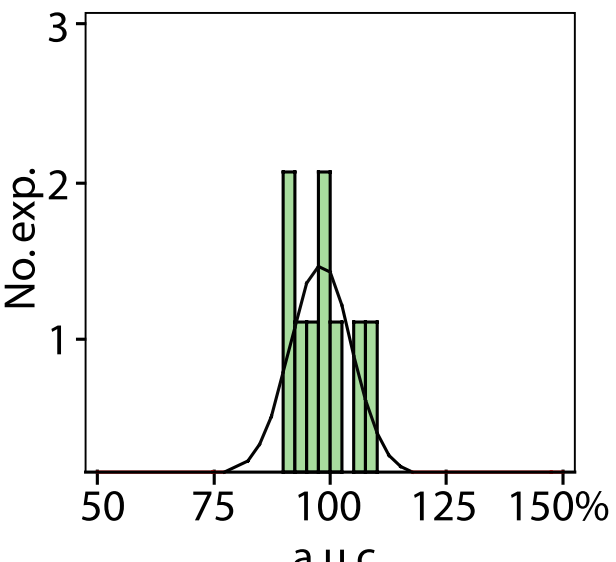

Figure 2

Reproducible $\mathrm{Ca}^{2+}$ responses at individual presynaptic varicosities evoked by brief tetanic stimulation. A. The recorded MSN is shown as a projection image created from a confocal z series of Alexa594 images. The area outlined (black rectangle) corresponds to the area imaged in panel B. B. OGI fluorescence image showing the stretch of axon contained one hot spot (arrowhead). The spline used is shown in red, superimposed on the OGI image. C. Spline scan images. Top image shows Alexa594, and bottom OGI. The timing of repetitive depolarizing pulses to evoke 10 action potentials is indicated on the time line (bottom). As compared to the Alexa594 trace, the OGI trace shows a stimulation-dependent increase in fluorescence intensity, which is shown in the line graphs in the next panel. D. Ca ${ }^{2+}$ imaging was repeated under control conditions (without drug application) at 10 min intervals, as diagramed on the time line. Raw traces are shown in blue, and smoothed traces (moving average of ten, see Methods) are superimposed in black. The total duration of the experiment was 40 min. The magnitude of the subsequent $\mathrm{Ca}^{2+}$ responses (measured as area under the curve, a.u.c.) expressed as a percent of the initial response is indicated below each trace. The $\mathrm{Ca}^{2+}$ responses varied less than $5 \%$. E. To test reproducibility, $\mathrm{Ca}^{2+}$ responses were evoked twice under control conditions (no drugs) and the a.u.c. of the second response was expressed as the percent of the first response $(n=9)$. The second response did not differ significantly from the first (see Results).

not respond to quinpirole, but showed clear facilitation with SKF81297.

As summarized in Figure 4, we recorded 13 varicosities from 6 cells with SKF81297 and 23 varicosities from 13 cells with quinpirole in wild type mice (the greater varia- bility in the quinpirole results required the additional experiments). Overall, SKF81297 produced facilitation (166 $\pm 17 \%$ of control), while quinpirole produced inhibition $(77 \pm 9 \%)$ (Figure $4 \mathrm{~A})$. As shown in the incidence data (Figure 4B), SKF81297 nearly always produced facilitation, while quinpirole produced predominantly inhibi- 

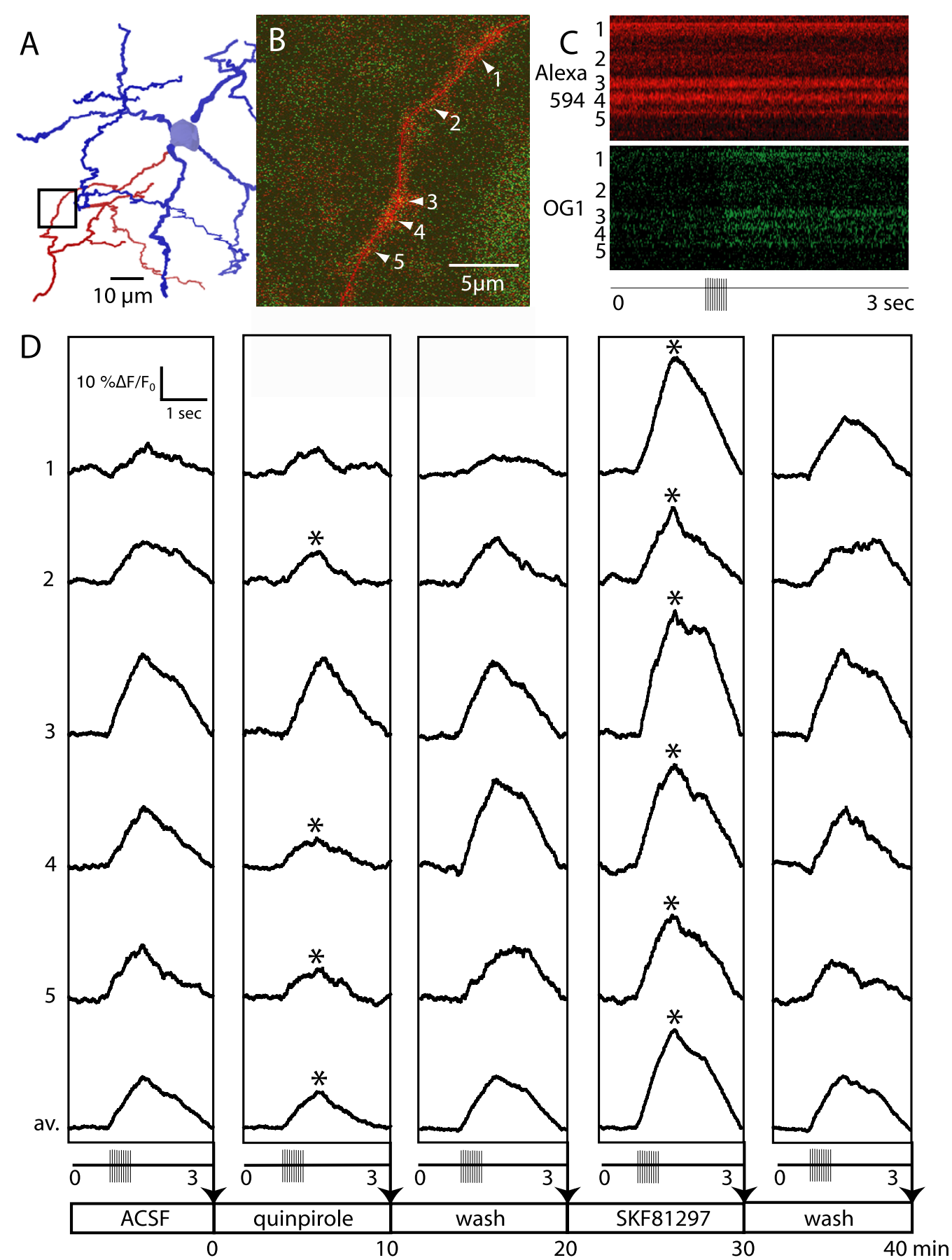

Figure 3

DI- and D2 modulation of individual varicosities on the same axonal segment. A. The MSN imaged is shown in a 3D reconstruction of a confocal z series of Alexa594 images. The cell body and multiple spiny dendrites are shown in blue and the single non-spine bearing axon is shown in red. The area imaged is outlined (black rectangle) and shown in panel B. B. In the OGI fluorescence image, the stretch of axon that contained five hot spots (numbered). The spline used for the time scan is shown as a red line superimposed on the axonal segment. $C$. The spline scan images show no change in the Alexa594 fluorescence and a stimulus-dependent increase in OGI fluorescence. D. $\mathrm{Ca}^{2+}$ imaging was carried out at 10 min intervals. The total duration of the experiment was $40 \mathrm{~min}$. Asterisks identify $\mathrm{Ca}^{2+}$ responses that were significantly modulated by DA (> 5\% of control). Note that the majority of varicosities showed modulation with both DI and D2 agonists. The relative magnitude of modulation was strikingly heterogeneous. 

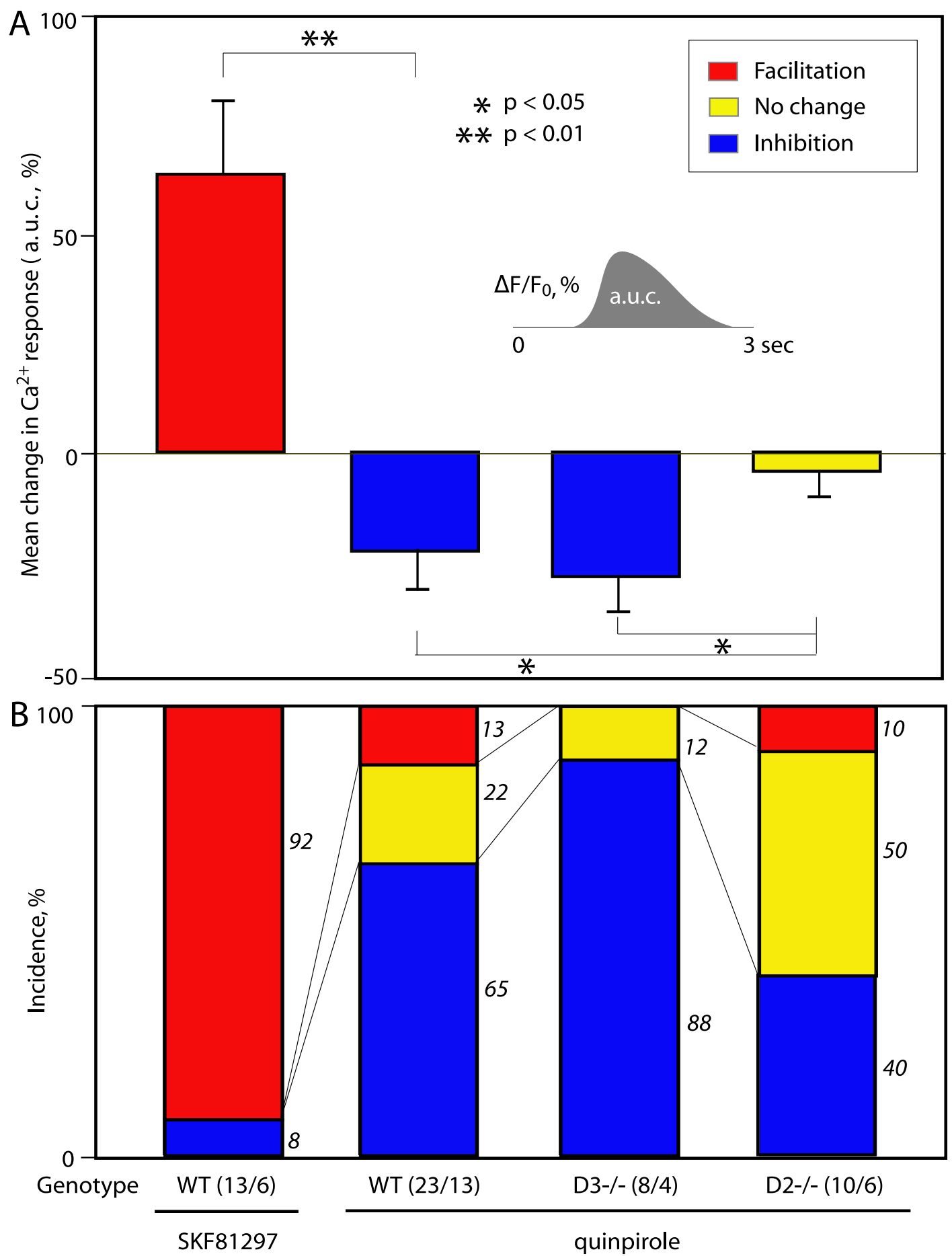

Figure 4

Summary of DA receptor agonist modulation in wild type and DA receptor $\mathrm{KO}$ mice. A. The mean change in $\mathrm{Ca}{ }^{2+}$ responses is shown for the full data set (bars are colored to indicate main effect). Asterisks mark significant differences. The quinpirole inhibition seen in WT and D3 KO mice was completely abolished in D2 KO mice $(p<0.05)$. B. The incidence of DA modulation was assessed using the $5 \%$ criterion (see text). Numbers in parentheses indicate the total number of varicosities and cells recorded, respectively. While DI stimulation with SKF8I 297 produced facilitation in almost all instances, D2 stimulation with quinpirole produced both inhibition and facilitation. Quinpirole facilitation seen in WT and D2 KO mice was completely abolished in D3 KO mice. 
tion, but in some instances facilitation, and in others it had no effect.

\section{Studies in DA receptor knockout mice}

Because quinpirole activates both D2 and D3 receptors [24], the heterogeneity in quinpirole modulation might reflect differential effects at D2 and D3 receptors. To address this, we made slices from D2 single, D3 single and $\mathrm{D} 2 / \mathrm{D} 3$ double knockout (KO) mice [25]. In a D2 KO mouse (Figure 5A-D), the area imaged contained a single hot spot that showed robust quinpirole facilitation $(164 \%$ of control; Figure 5D), presumably D3 receptor-mediated. In a D3 KO mouse (Figure 5E-H), the area imaged contained 3 hot spots. Hot spot \#2 showed significant inhibition (53\% of control), presumably D2 receptor-mediated, while \#1 and 3 showed no effect (Figure 5H).

As also summarized in Figure 4, quinpirole inhibition was apparently normal in D3 KO mice, while it was largely abolished in D2 KO mice (Figure 4A), suggesting that the predominant inhibitory effect was D2 receptor-mediated. In $\mathrm{D} 2 \mathrm{KO}$ mice, the incidence of quinpirole inhibition was diminished (Figure 4B), while the no effect incidence increased. However, quinpirole-mediated inhibition remained in D2 KO mice, suggesting that D3 receptors must also mediate inhibition. While the incidence of quinpirole-induced facilitation remained almost the same in D2 KO mice, it was undetectable in D3 KO mice. Thus, D2 receptors appeared to mediate inhibition, while D3 receptors appeared to mediate either inhibition or facilitation. The incidence of quinpirole-mediated inhibition was slightly increased in D3 KO mice, which may reflect a compensatory increase in $\mathrm{D} 2$ receptor expression due to the lack of D3 receptors, as D2 and D3 receptors may exert feedback control on their expression [25].

\section{Heterogeneity in DA modulation}

The correlation between the magnitude of SKF81297 or quinpirole-mediated modulation and the distance from soma to the recorded varicosities was subjected to regression analysis (see additional file 2). For both SKF81297 and quinpirole application, the data were randomly distributed, showing no relationship to distance from the soma. In the experiments where we were able to image more than one varicosity on the same axon $(\mathrm{n}=12)$, heterogeneity in DA modulation was readily apparent. To look for a spatial pattern more closely, we graphed DA modulatory effects at individual varicosities as a function of their distance from the cell body in a bubble plot (Figure 6). In experiment 8, where we tested both SKF81297 and quinpirole in wild type mice, hot spots \#1 and \#3 showed robust SKF81297-mediated facilitation but weak quinpirole-mediated inhibition, while \#4 showed robust quinpirole-mediated inhibition and weaker SKF81297mediated facilitation. Varicosity \#2 and the most distal varicosity showed equally robust SKF81297-mediated facilitation and quinpirole-mediated inhibition. In experiment 12, where we tested both SKF81297 and quinpirole in a D3KO mouse, the most proximal hot spot was unaffected, while the second showed only quinpirole-mediated inhibition, and the third showed both SKF81297mediated facilitation and quinpirole-mediated inhibition. Thus, the relative responsiveness to D1 and D2 receptor activation varied considerably from varicosity to varicosity along the axon, with no proximal-distal pattern.

\section{Discussion}

We examined DA modulation of medium-spiny neuron synapses by visualizing activity-dependent $\mathrm{Ca}^{2+}$ responses at multiple presynaptic varicosities on proximal axons of individual MSNs. $\mathrm{Ca}^{2+}$ responses showed potent DA modulation, with subsets of varicosities showing both D1 and D2 pharmacology. D1 receptors were almost exclusively facilitatory, while D2 receptors were inhibitory, and D3 receptors either inhibitory or facilitatory. Along single axonal processes DA modulation varied strikingly from varicosity to varicosity.

\section{Modulatory role of presynaptic DA receptors}

The D1 agonist SKF81297 produced reliable facilitation of presynaptic $\mathrm{Ca}^{2+}$ responses, while the D2/D3 agonist quinpirole produced either facilitation or inhibition. This was consistent with our previous cell culture observations [26], as well as recent observations in isolated striatal synaptosomes [27]. Due to the lack of D3 receptors in the dorsal striatum [28], the inhibition of synaptic currents with a D2/D3 agonist observed by Guzman et al. [11] was presumably mediated by $\mathrm{D} 2$ receptors. In the nAcc, where D3 receptors are robustly expressed, dissecting D2 actions becomes more complicated.

Given the limited selectivity of available D2 agonists, one approach might be to use DA in combination with more selective than DA antagonists [29]. However, there are potential confounds in such an approach, including instability of DA, differential accessibility of DA and DA antagonists to receptors in the slice and limited reversibility of antagonists due to their lipophilicity. [30-33]. We therefore opted to use D2 and D3 KO mice. In D2 KO mice, the inhibitory effect of quinpirole was diminished, indicating that D2 receptors mediate inhibition. The facilitatory effect of quinpirole was eliminated in $\mathrm{D} 3 \mathrm{KO}$ mice, while it remained in $\mathrm{D} 2 \mathrm{KO}$ mice, indicating that $\mathrm{D} 3$ receptors mediate facilitation. However, some inhibition remained in $\mathrm{D} 2 \mathrm{KO}$ mice, indicating that $\mathrm{D} 3$ receptors may mediate either facilitation or inhibition.

We can discount a role for D4 receptors in the modulation of nAcc MSN synapses. Results from in situ hybridization $[28,34]$ and immunohistochemistry $[35,36]$, which reveal 

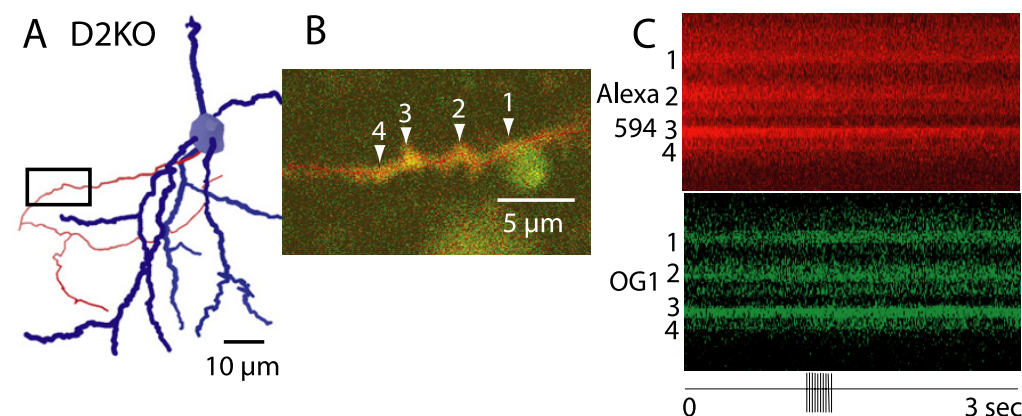

$\mathrm{D}$
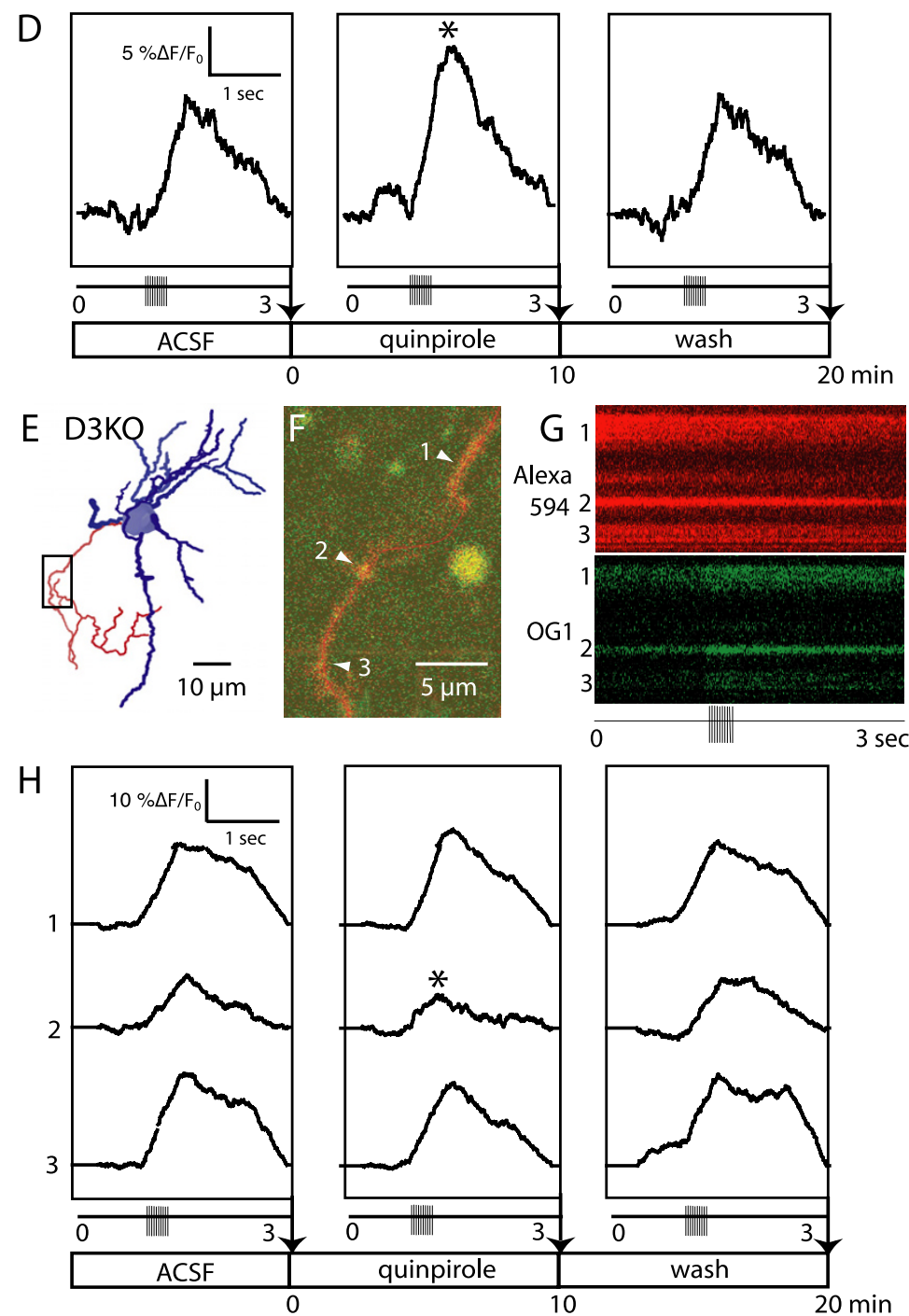

Figure 5

Dissection of quinpirole effects using D2 and D3 KO mice. A. A 3D reconstruction of a MSN from a D2 KO mouse is shown with the cell body and dendrites in blue and the axon in red. The area outlined (black rectangle) corresponds to the area imaged in panel B. B. The OGI image contained four hot spots (numbered). C. Spline scan image. Top panel shows Alexa594, and bottom panel shows OGI. In the OGI image, only varicosity \#4 showed a Ca ${ }^{2+}$ response. D. In this D2 $\mathrm{KO}$ cell, quinpirole facilitated the $\mathrm{Ca}^{2+}$ response. E. 3D reconstruction of a MSN from a D3 KO mouse. The area outlined (black rectangle) corresponds to the area imaged in panel F. F. The area imaged contained three hot spots (numbered). G. Spline scan image. Top panel shows Alexa594, and bottom panel shows OGI. H. In this D3 KO cell, quinpirole inhibited varicosity \#2 (*), but had no effect on varicosities \#I and 3 . 


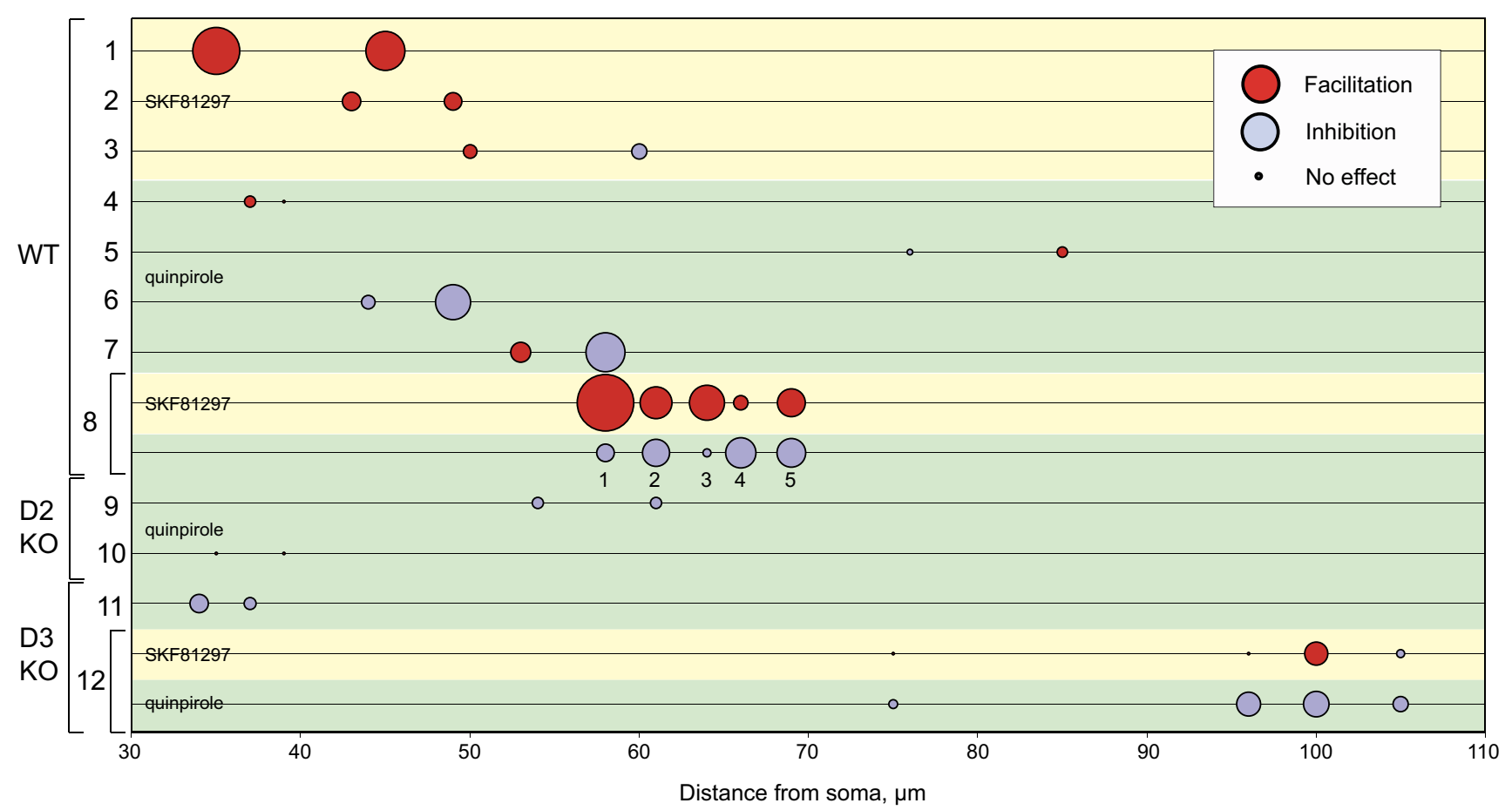

\section{Figure 6}

DA receptor-mediated modulation is heterogeneous. Bubble plot of spatial distribution of varicosities and magnitude of DA receptor-mediated modulation in wild type and D2 and D3 KO mice. The distance of imaged varicosities from the soma is indicated along the $x$-axis. Bubble area is proportional to the magnitude of modulation. Facilitation is shown in red and inhibition in purple. In experiments two experiments, both SKF8I297 and quinpirole were tested sequentially in the same cell (experiments 8 and 12). In experiment 8 (data shown in Figure 3), the majority of varicosities showed both DI receptor-mediated facilitation and D2 receptor-mediated inhibition, but the magnitude of modulation varied strikingly among individual varicosities. In experiment 12, in a D3 KO mouse, the third varicosity showed both SKF8I297-mediated facilitation and quinpirolemediated inhibition, indicating colocalization of DI and D2 receptors.

D3 receptor expression in about $20 \%$ of MSNs, show negligible D4 receptor expression. No D4 receptor expression was seen in the striatum or nAcc of Drd4-EGFP transgenic mice, in which enhanced green fluorescent protein (EGFP) was introduced using bacterial artificial chromosome (BAC) technology and expressed under the control of genomic fragments flanking the D4 receptor gene locus [37]. Electron microscopic immunohistochemistry revealed some D4 receptor expression in dendritic spines of a minority of MSNs [38], consistent with physiological evidence that D4 actions are postsynaptic [29]. In two preliminary experiments in $\mathrm{D} 2 / 3$ double $\mathrm{KO}$ mice (not shown), quinpirole had no effect, confirming that effects of quinpirole are mediated by D2 or D3 receptors, but not D4 receptors. Thus, D4 receptors are unlikely to have a role in the presynaptic modulation of MSNs.
D3 receptors may mediate more heterogeneous actions as they are not robustly coupled to $G_{i}$ in many mammalian expression systems [39]. Furthermore, the third intracellular loop, which is important for the G protein coupling, is highly divergent in D3 receptors with only a $\sim 25 \%$ homology in amino acid sequence to the D2 sequence, suggesting a divergence in coupling. For instance, phosphorylation of $\mathrm{G}$ protein coupled receptors can switch them from $\mathrm{G}_{\mathrm{s}}$ to $\mathrm{G}_{\mathrm{i}}$-coupled in an activity-dependent fashion [40]. It is thus possible that the coupling of the D3 receptor is not only more heterogeneous, but probably plastic.

\section{Co-localization of DI and D2 receptors with distinct functions on intrinsic synapses}

Although the dominant view of DA receptor expression in striatal neurons asserts strict cellular segregation [41,42], several studies [26,43-51] have suggested that D1- and 
D2-like receptors are co-expressed in single MSNs. Here, we have shown that subsets of presynaptic varicosities D1 pharmacology, others D2, and many both D1 and D2 pharmacology. This suggests a resolution to these apparently contradictory findings - DA receptors may be differentially trafficked to different presynaptic varicosities in MSN axons $[17,26]$. As D1 receptors mediate facilitatory effects while D2-like receptors mediate predominantly inhibitory effects, DA could be either facilitatory or inhibitory - with varying potency - depending on the relative preponderance of functional D1 and D2-like receptors on individual varicosities.

\section{DA differentially modulates intrinsic synapses}

The DA agonists triggered strikingly divergent effects at different varicosities, including adjacent varicosities on the same axon, presumably reflecting heterogeneity in the relative abundance of functional DA receptors on individual varicosities. In light of accumulating evidence that the distribution of many receptors is dynamically regulated by recruitment to postsynaptic sites, internalization and differential recycling [52], it seems plausible that the distribution of DA receptors on individual presynaptic varicosities might also vary considerably. In fact, this appears to be the case for MSN projection axons. Anatomical tracing studies have confirmed that all MSNs project to the pallidum, with about one third terminating there, and the remaining two thirds extending to the entopeduncular nucleus and the ventral midbrain [53,54]. Physiological studies have shown that these projections are differentially modulated by DA; projections to pallidal neurons are inhibited by D2 receptor activation [55], while projections to the ventral midbrain are facilitated by D1 receptor activation $[56,57]$. These observations can be reconciled if D1 and D2 receptors are coexpressed in MSN cell bodies but differentially trafficked in the axons of a given MSN [17].

Several lines of evidence support the idea that DA receptors undergo differential trafficking. Alternatively spliced D2 receptor isoforms (D2S and D2L) are differentially targeted to different presynaptic terminals, where they mediate distinct functions [58]. Consistent with this, we found in D3KO mice that the effect of quinpirole was heterogeneous, indicating that D2 receptors are heterogeneously distributed. Alternatively, DA receptors might be uniformly trafficked to all presynaptic terminals, but differentially distributed between surface (functional) and intracellular (nonfunctional) compartments. For example, D2 receptors are selectively sorted to degradation pathways, while D1 receptors are preferentially recycled back to the surface [59]. Consequently, synapses expressing DA receptors may have an altered expression profile depending on prior DA exposure. This suggests that the differential distribution of DA receptors observed at a given moment might reflect past patterns of DA release.

\section{Microdomains in DA receptor-mediated signaling}

How could the observed DA receptor-mediated modulation be so spatially restricted? Voltage-dependent $\mathrm{Na}^{+}$or $\mathrm{K}^{+}$channels are modulated directly by DA $[43,60,61]$, which should control presynaptic $\mathrm{Ca}^{2+}$ influx. But this is unlikely to account for the micro-heterogeneity we observed, since the varicosities recorded were often quite close together and were therefore probably isopotential. In contrast, CAMP which was in earlier studies thought to rapidly diffuse through the cytosol $[62,63]$, has been found in more recent studies, using sensitive biosensors, to be restricted in its diffusion to microdomains. [64-66]. Molecules diffuse more slowly in the cytosol due to the molecular crowding effect [67], which would be slowed further by the confinement effect of the narrow bore of axon. Restricted signaling might be further ensured by the recruitment of active enzymes into close proximity of $\mathrm{Ca}^{2+}$ channels through the interaction with scaffold proteins. [68-70]. For instance, in dendritic spines, $\mathrm{Ca}^{2+}$ rises are modulated by $G$ protein-coupled receptors through the activation of protein kinase $A$ in a spatially restricted manner [71]. Thus, the assembly of a multimeric signaling complex together with restricted diffusion of second messengers should enable local DA modulation of nearby $\mathrm{Ca}^{2+}$ channels.

Synaptic vesicle release is triggered by clustered presynaptic $\mathrm{Ca}^{2+}$ channels that produce discrete domains of elevated intracellular $\mathrm{Ca}^{2+}$. Among the members of the Cav2 calcium channel family that mediate the presynaptic $\mathrm{Ca}^{2+}$ rise, $\mathrm{N}$-type and $\mathrm{P} / \mathrm{Q}$-type channels are found on synapses interconnecting MSNs [72], and are subject to DA modulation [73]. Due to cooperativity amongst clustered $\mathrm{Ca}^{2+}$ channels, the channels may function as a single $\mathrm{Ca}^{2+}$ entry site [74]. But because of the non-linear relationship between $\mathrm{Ca}^{2+}$ influx and vesicle release, modest modulatory effects on individual $\mathrm{Ca}^{2+}$ channels should translate into more dramatic changes in transmitter release, while at the same time restricting modulatory effects to subcellular microdomains [75]. Thus, the DA modulation of $\mathrm{Ca}^{2+}$ responses we observed could control GABA release at individual MSN varicosities and therefore play a role in encoding striatal information processing.

\section{Conclusion}

The present results raise the intriguing hypothesis that the differential distribution of DA receptors reflects past patterns of DA synaptic activity, and may thus be a novel site for enduring synaptic plasticity. Intrinsic connections may be viewed as the hidden layer in a Hopfield network [76] - so their modulation would be expected to shape information flow through the area and confer greater compu- 
tational capacity for motor and reward-related learning. The multiplicity of DA receptor actions in combination with their differential distribution could produce large variations in DA responsiveness at individual synapses. Conceivably, aberrant patterns of DA receptor activation could induce pathologic changes in the distribution of DA receptors, giving rise to disorganized information flow, and ultimately to aberrant motor or appetitive behaviors.

\section{Methods}

\section{Slice preparation}

All animal procedures were reviewed and approved by the Institutional Animal Care and Use Committees of Columbia University and the New York State Psychiatric Institute and were in compliance with the USPHS Guide for the Care and Use of Laboratory Animals. Slices were prepared from postnatal day 11-13 congenic C57BL/6 and 129 wild type or congenic C57BL/6 D2, D3 or D2/D3 receptor knockout (KO) mice [25] following standard procedures. Animals were deeply anesthetized with ketamine/xylazine, and their brains rapidly removed into ice-cold artificial cerebrospinal fluid (ACSF Recipe1, in mM: $125 \mathrm{NaCl}, 2.5 \mathrm{KCl}$, $25 \mathrm{NaHCO}_{3}, 1.25 \mathrm{NaH}_{2} \mathrm{PO}_{4}, 2 \mathrm{CaCl}_{2}, 1 \mathrm{MgCl}_{2}, 25$ glucose; $\mathrm{pH} 7.4$ ) saturated with $95 \% \mathrm{O}_{2}-5 \% \mathrm{CO}_{2}$. Using a vibratome, $300 \mu \mathrm{m}$ thick parasagittal slices were cut encompassing the projection from the nucleus accumbens (nAcc) to the adjacent ventral pallidum (VP). After 1 hour recovery, slices were placed in the recording chamber (about $1 \mathrm{ml}$ capacity) on the stage of an upright fluorescence microscope (LSM510, Carl Zeiss MicroImaging, Thornwood, NY) and held down with a custom-made harp made from platinum wire. During recording and imaging, the recording chamber was continuously perfused with ACSF (Recipe2: $125 \mathrm{NaCl}, 2.5 \mathrm{KCl}, 25$ $\mathrm{NaHCO}_{3}, 1.25 \mathrm{NaH}_{2} \mathrm{PO}_{4}, 3 \mathrm{CaCl}_{2}, 0 \mathrm{MgCl}_{2}, 25$ glucose; pH7.4) saturated with $95 \% \mathrm{O}_{2}-5 \% \mathrm{CO}_{2}$ at about $1 \mathrm{ml} /$ min. Recordings were done at $\sim 20^{\circ} \mathrm{C}$, to optimize data acquisition; working at room temperature increased stability in both the recording and imaging, and improved the temporal resolution by slowing the response kinetics.

\section{Whole cell patch clamp recording}

Using IR-DIC microscopy, visually-guided whole cell recordings were obtained with patch pipettes filled with an intracellular solution (130 KCl, $4.6 \mathrm{MgCl}_{2}, 10 \mathrm{HEPES}$, $\left.4 \mathrm{ATP} \cdot \mathrm{Na}_{2}, 0.4 \mathrm{GTP} \cdot \mathrm{Na}, \mathrm{pH} 7.25\right)$ containing $100 \mu \mathrm{M}$ Oregon Green 488 BAPTA-1 (OG1) and $10 \mu \mathrm{M}$ Alexa 594 (Molecular Probes/Invitrogen, Carlsbad, CA). Patch pipettes were fabricated from standard wall borosilicate glass capillary tubes with filament (Harvard Apparatus, Holliston, MA) and had access resistances of 4-8 $\mathrm{M} \Omega$. During dye loading (30 min), access resistance typically increased to about $13-15 \mathrm{M} \Omega$, probably due to partial resealing, and then remained constant for the rest of the experiment. Cells were voltage clamped at $-70 \mathrm{mV}$, with- out series resistance compensation, using an Axopatch 200 amplifier (Axon Instruments/Molecular Devices, Sunnyvale, CA) coupled to an ITC-18 A/D interface (InstruTech, Port Washington, NY). Generation of pulse patterns and monitoring of whole cell currents were done with PulseControl XOPs [Richard J. Bookman, University of Miami School of Medicine, Department of Medical Network Services, Miami, FL, [77]] running under IgorPro (WaveMetrics, Lake Oswego, OR). Stimulus parameters were adjusted so that depolarizing steps (50 mV, $1 \mathrm{msec}$ ) reliably evoked action potentials without failure.

\section{Two-photon calcium imaging}

Once in whole-cell mode, the fluorescent dyes were allowed to diffuse into cells and their processes for a minimum of $30 \mathrm{~min}$ or until Alexa594 fluorescence reached a plateau in proximal varicosities. Dye diffusion was followed in sequential images taken at 10 min intervals. The recorded cell was imaged to confirm the identification of the cell as a MSN according to morphological criteria, specifically cell body diameter of $\sim 10 \mu \mathrm{m}$ (medium-sized) and the presence of multiple spiny dendrites. A single non-spine-bearing axonal process was readily discerned, after the longer time necessary for diffusion into the axon due to its narrower bore (see Figure 1A).

2PLSM $\mathrm{Ca}^{2+}$ imaging procedures followed established methodology $[20,78,79]$. We used a Zeiss LSM510 equipped with a direct-coupled Ti:sapphire laser (Mira Model 900F, Coherent, Santa Clara, CA) tuned to $850 \mathrm{~nm}$ (excitation wavelength). Presynaptic $\mathrm{Ca}^{2+}$ transients evoked by repetitive action potentials propagation were recorded by monitoring the fluorescence intensity of OG1. Cells were stimulated with a brief high-frequency train (ten $1 \mathrm{msec}$ depolarizing pulses at $50 \mathrm{~Hz}$, for 200 $\mathrm{msec}$ ) to evoke ten action potentials without failure. This produced a constant, submaximal (unsaturated) $\mathrm{Ca}^{2+}$ response. Changes in the $\mathrm{Ca}^{2+}$ signal, $\% \Delta \mathrm{F} / \mathrm{F}_{\mathrm{o}}=\%\left(\mathrm{~F}-\mathrm{F}_{\mathrm{o}}\right) / \mathrm{F}_{\mathrm{o}}$ (where $\mathrm{F}_{\mathrm{O}}$ = average of OG1 fluorescence intensity before delivery of depolarization pulses), were measured at 10 msec intervals for $3 \mathrm{sec}$ in line-scan mode. TTL trigger pulses were sent from Igor Pro to synchronize the acquisition of membrane current traces, line-scan images and the train stimulation. $\mathrm{Ca}^{2+}$ rises were typically restricted to short brighter stretches or swellings of axons identified in the Alexa 594 images, which were well suited for line scanning $[19,21]$.

To define a free shape curve (spline) as the scan line, a mouse-drawn line was superimposed on well-focused stretches of axon containing multiple varicosities, and saved and reused for subsequent imaging. However, if the contour of the defined spline was too tortuous, the scanner path was artifactually displaced with respect to the spline. To compensate for this, the X, Y offset was adjusted 
to bring the scanner line back into register with the spline. If this was not sufficient, then the spline was simplified so that the scanner followed the spline exactly. The LSM software generated a profile of fluorescence intensity along the spline on which hot spots (points with higher fluorescence intensity) were readily identified. Their locations along the axon were measured in the $3 \mathrm{D}$ reconstruction generated from z-series of Alexa 594 images using Neurolucida and Neurolucida Explorer (MicroBrightfield, Williston, VT).

\section{Drug application}

The selective D1/D5 agonist SKF81297 (1 $\mu \mathrm{M})$ or the D2/ D3 agonist quinpirole $(20 \mu \mathrm{M})$ were applied via bath perfusion. Drug effects took about $5 \mathrm{~min}$ to reach a plateau (or wane), so we measured $\mathrm{Ca}^{2+}$ responses at 10 min intervals. To avoid residual drug effects, we recorded from only one cell in each slice.

\section{Data analysis}

Acquired data were analyzed with LSM Examiner software (Carl Zeiss MicroImaging) and Image [Wayne S. Rasband, National Institutes of Health, Bethesda, MD, [80]]. Changes in the $\mathrm{Ca}^{2+}$ signal were calculated as $\% \Delta \mathrm{F} / \mathrm{F}_{\mathrm{O}^{\prime}}$ which normalizes for slow shifts in baseline fluorescence $[19,79]$. The area under the curve (a.u.c., integration) of unmodified raw traces was calculated using Igor Pro. Representative $\mathrm{Ca}^{2+}$ responses were smoothed by a moving average method using Igor Pro, in which each data point was replaced by the average of the 10 preceding and 10 following points. Statistical comparisons were made using JMP (SAS Institute, Cary, NC). To detect the difference between two independent comparison groups, an appropriate $t$ test was chosen based on the result of the Ftest. When the result of the Ftest indicated that the variances of the comparison groups were not significantly different ( $p$ $>0.05)$ ), the two-tail student $t$ test was used. When the result of the Ftest indicated that the variances of the comparison groups are significantly different $(\mathrm{p}<0.05)$, Welch's $t$ test was used. Graphs were created using Igor Pro and JMP.

\section{Authors' contributions}

TM designed and conducted the experiments. CS suggested the use of D2/D3 KO mice to dissect the D2 pharmacology, provided D2, D3 single and D2/D3 double KO mice, and critical insights throughout. SR conceived and directed the project. TM and SR wrote the manuscript. All three authors read and approved the final manuscript.

\section{Additional material}

\section{Additional File 1}

Functional intrinsic synapses. Electrophysiological demonstration of functional intrinsic synapses formed by MSNs in the parasagittal brain slices. We found that making parasagittal slices, in which the projection axons of MSNs extending from nAcc to ventral pallidum (VP) were most likely to be intact, was crucial for recording $\mathrm{Ca}^{2+}$ responses from the intrinsic synapses. Subsets of projection axons were stimulated with a bipolar electrode placed in the VP (schematized in left panel; arrow in right panel indicated the stimulus artifact), according to the previously established protocol $[11,18]$. Spikes in MSN axons conducted antidromically to the soma in the nAcc and then orthodromically into their local axons to activate their intrinsic synapses. This produced a complex IPSC (right panel, top trace) that was completely blocked by the $G A B A_{A}$ antagonist bicuculline (middle trace). Following wash, the drug effect partially reversed (bottom trace). Thus, MSN intrinsic synapses are functional in our slice preparation. File is in pdf format.

Click here for file

[http://www.biomedcentral.com/content/supplementary/14712202-8-8-S1.pdf]

\section{Additional File 2}

Spatial correlation of dopamine modulation. Scatter diagram of spatial correlation between the magnitude of D1 (SKF81297) or D2/D3 (Quinpirole) modulation (expressed as the percent of the preceding control response) and the distance from soma to the recorded varicosities $(\mu \mathrm{m})$. The sample correlation coefficient (Pearson Correlation Coefficient) was denoted as $r$. For both SKF81297 (left) and quinpirole (right), data were randomly distributed with weak linearity. File is in pdf format.

Click here for file

[http://www.biomedcentral.com/content/supplementary/14712202-8-8-S2.pdf]

\section{Acknowledgements}

We thank Sudhindra Swamy and Theresa Swayne for imaging support, and Mihran Bakalian and Edward Fung for help with Neurolucida. We thank Nao Chuhma, Arnold Kriegstein, James Monckton, Timothy Ryan, Stanislav Zakharenko and Haining Zhong for advice and critical discussion. This work was supported by the Whitehall Foundation (SR), the National Institute on Drug Addiction (SR), the National Institute of Mental Health (CS), the Frontier Fund of the Columbia Department of Psychiatry (TM) and the National Alliance for Research on Schizophrenia and Depression (TM).

\section{References}

I. Floresco SB, West AR, Ash B, Moore H, Grace AA: Afferent modulation of dopamine neuron firing differentially regulates tonic and phasic dopamine transmission. Nat Neurosci 2003, 6(9):968-973.

2. Bonci A, Bernardi G, Grillner P, Mercuri NB: The dopamine-containing neuron: maestro or simple musician in the orchestra of addiction? Trends Pharmacol Sci 2003, 24(4): 172-177.

3. Marinelli M, Rudick CN, Hu XT, White FJ: Excitability of dopamine neurons: modulation and physiological consequences. CNS Neurol Disord Drug Targets 2006, 5(I):79-97.

4. Wilson CJ: Basal ganglia. In The Synaptic Organization of the Brain Fifth edition. Edited by: Shepherd GM. New York: Oxford University Press; 2004:36I-4I3.

5. Tepper JM, Bolam JP: Functional diversity and specificity of neostriatal interneurons. Curr Opin Neurobiol 2004, I 4(6):685.

6. Kita H, Kosaka T, Heizmann CW: Parvalbumin-immunoreactive neurons in the rat neostriatum: a light and electron microscopic study. Brain Res 1990, 536(I-2): I-I5. 
7. Koos T, Tepper JM: Inhibitory control of neostriatal projection neurons by GABAergic interneurons. Nat Neurosci 1999, 2(5):467-472.

8. Jaeger D, Kita H, Wilson C): Surround inhibition among projection neurons is weak or nonexistent in the rat neostriatum. J Neurophysiol 1994, 72(5):2555-2558.

9. Koos T, Tepper JM, Wilson CJ: Comparison of IPSCs evoked by spiny and fast-spiking neurons in the neostriatum. J Neurosci 2004, 24(36):7916-7922.

10. Gustafson N, Gireesh-Dharmaraj E, Czubayko U, Blackwell KT, Plenz $\mathrm{D}$ : A comparative voltage and current-clamp analysis of feedback and feedforward synaptic transmission in the striatal microcircuit in vitro. J Neurophysiol 2006, 95(2):737-752.

II. Guzman JN, Hernandez A, Galarraga E, Tapia D, Laville A, Vergara R, Aceves J, Bargas J: Dopaminergic modulation of axon collaterals interconnecting spiny neurons of the rat striatum. J Neurosci 2003, 23(26):893।-8940.

12. Tunstall MJ, Oorschot DE, Kean A, Wickens JR: Inhibitory interactions between spiny projection neurons in the rat striatum. J Neurophysiol 2002, 88(3): 1263-1269.

13. Czubayko U, Plenz D: Fast synaptic transmission between striatal spiny projection neurons. Proc Natl Acad Sci USA 2002 99(24):15764-15769.

14. Nicola SM, Surmeier DJ, Malenka RC: Dopaminergic modulation of neuronal excitability in the striatum and nucleus accumbens. Annu Rev Neurosci 2000, 23:185-215.

15. Nicola SM, Malenka RC: Dopamine depresses excitatory and inhibitory synaptic transmission by distinct mechanisms in the nucleus accumbens. J Neurosci 1997, I7(I5):5697-57I0.

16. Taverna S, Canciani B, Pennartz CM: Dopamine DI-receptors modulate lateral inhibition between principal cells of the nucleus accumbens. J Neurophysiol 2005, 93(3):1816-1819.

17. Surmeier DJ, Reiner A, Levine MS, Ariano MA: Are neostriatal dopamine receptors co-localized? Trends Neurosci 1993, 16(8):299-305.

18. Chang HT, Kitai ST: Projection neurons of the nucleus accumbens: an intracellular labeling study. Brain Res 1985, 347:112-116.

19. Llano I, Tan YP, Caputo C: Spatial heterogeneity of intracellular $\mathrm{Ca}^{2+}$ signals in axons of basket cells from rat cerebellar slices. J Physiol (Lond) 1997, 502(Pt 3):509-519.

20. Cox CL, Denk W, Tank DW, Svoboda K: Action potentials reliably invade axonal arbors of rat neocortical neurons. Proc Nat Acad Sci USA 2000, 97( (17):9724-9728.

21. Koester HJ, Sakmann B: Calcium dynamics associated with action potentials in single nerve terminals of pyramidal cells in layer 2/3 of the young rat neocortex. J Physiol 2000, 529(Pt 3):625-646.

22. Neher $E$, Augustine $G$ J: Calcium gradients and buffers in bovine chromaffin cells. J Physiol 1992, 450:273-30I.

23. Huguenard JR: Reliability of axonal propagation: the spike doesn't stop here. Proc Natl Acad Sci USA 2000, 97( I 7):9349-9350.

24. Neve KA, Neve RL: Molecular biology of dopamine receptors. In The Dopamine Receptors Edited by: Neve KA, Neve RL. Totowa, NJ: Humana Press; 1997:27-76.

25. Jung M-Y, Skryabin BV, Arai M, Abbondanzo S, Fu D, Brosius J, Robakis NK, Polites HG, Pintar JE, Schmauss C: Potentiation of the D2 mutant motor phenotype in mice lacking dopamine D2 and D3 receptors. Neuroscience 1999, 91(3):9| I-924.

26. Geldwert D, Norris JM, Feldman IG, Schulman JJ, Joyce MP, Rayport $S$ : Dopamine presynaptically and heterogeneously modulates nucleus accumbens medium-spiny neuron GABA synapses in vitro. BMC Neurosci 2006, 7:53.

27. Wu J, Dougherty J], Nichols RA: Dopamine receptor regulation of $\mathrm{Ca2}+$ levels in individual isolated nerve terminals from rat striatum: comparison of presynaptic DI-like and D2-like receptors. J Neurochem 2006, 98(2):48I-494.

28. Le Moine C, Bloch B: Expression of the D3 dopamine receptor in peptidergic neurons of the nucleus accumbens: comparison with the DI and D2 dopamine receptors. Neuroscience 1996, 73(I): $131-143$.

29. Hernandez A, Ibanez-Sandoval O, Sierra A, Valdiosera R, Tapia D Anaya-Martinez V, Galarraga E, Bargas J, Aceves J: Control of the subthalamic innervation of the rat globus pallidus by $D 2 / 3$ and D4 dopamine receptors. I Neurophysiol 2006, 96(6):2877-2888
30. Rayport S, Sulzer D: Visualization of antipsychotic binding to living mesolimbic neurons reveals D2 receptor mediated, acidotropic and lipophilic components. I Neurochem 1995, 65(2):69|-703.

31. Mathis CA, Bishop JE, Gerdes JM, Whitney JM, Brennan KM, Jagust $W]$ : Synthesis and evaluation of high affinity, aryl-substituted [18F] fluoropropylbenzamides for dopamine D-2 receptor studies. Int J Rad Appl Instrum B 1992, 19(5):571-588.

32. Mukherjee J, Yang ZY, Das MK, Brown T: Fluorinated benzamide neuroleptics - III. Development of (S)-N-[( I-allyl-2-pyrrolidinyl)methyl]-5-(3-[ $\left.{ }^{18} \mathrm{~F}\right]$ fluoropropyl)-2, 3-dimethoxybenzamide as an improved dopamine D-2 receptor tracer. Nuc Med Biol I995, 22(3):283-296.

33. Baindur N, Tran M, Niznik HB, Guan HC, Seeman P, Neumeyer JL: (+-)-3-Allyl-7-halo-8-hydroxy-I-phenyl-2,3,4,5-tetrahydroI H-3-benzazepi es as selective high affinity DI dopamine receptor antagonists: Synthesis and structure-activity relationship. I Med Chem 1992, 35:67-72.

34. Landwehrmeyer B, Mengod G, Palacios JM: Differential visualization of dopamine D2 and D3 receptor sites in rat brain. $A$ comparative study using in situ hybridization histochemistry and ligand binding autoradiography. Eur J Neurosci 1993, 5:145-153.

35. Mrzljak L, Bergson C, Pappy M, Huff R, Levenson R, Goldman-Rakic PS: Localization of dopamine D4 receptors in GABAergic neurons of the primate brain. Nature 1996, 38 I(6579):245-248.

36. Ariano MA, Wang J, Noblett KL, Larson ER, Sibley DR: Cellular distribution of the rat D4 dopamine receptor protein in the CNS using anti-receptor antisera. Brain Res 1997, 752(12):26-34.

37. Noain D, Avale ME, Wedemeyer C, Calvo D, Peper M, Rubinstein M: Identification of brain neurons expressing the dopamine D4 receptor gene using BAC transgenic mice. Eur J Neurosci 2006, 24(9):2429-2438.

38. Svingos AL, Periasamy S, Pickel VM: Presynaptic dopamine $\mathbf{D}_{4}$ receptor localization in the rat nucleus accumbens shell. Synapse 2000, 36(3):222-232.

39. Sibley DR, Neve KA: Regulation of dopamine receptor function and expression. In The Dopamine Receptors Edited by: Neve KA, Neve RL. Totowa, NJ: Humana Press; 1997:383-424.

40. Baillie GS, Sood A, McPhee I, Gall I, Perry SJ, Lefkowitz RJ, Houslay MD: $\beta$-Arrestin-mediated PDE4 CAMP phosphodiesterase recruitment regulates $\beta$-adrenoceptor switching from $\mathbf{G}_{\mathbf{s}}$ to G. Proc Natl Acad Sci USA 2003, I 00(3):940-945

4I. Gerfen CR, Engber TM, Mahan LC, Susel Z, Chase TN, Monsma FJ, Sibley DR: DI and D2 dopamine receptor-regulated gene expression of striatonigral and striatopallidal neurons. Science 1990, 250:| 1429-| 432.

42. Le Moine C, Bloch B: DI and D2 dopamine receptor gene expression in the rat striatum: sensitive CRNA probes demonstrate prominent segregation of $D I$ and $D 2$ mRNAs in distinct neuronal populations of the dorsal and ventral striatum. J Comp Neurol 1995, 355(3):418-426.

43. Surmeier DJ, Kitai ST: DI and D2 dopamine receptor modulation of sodium and potassium currents in rat neostriatal neurons. Prog Brain Res 1993, 99:309-324.

44. Surmeier DJ, Eberwine J, Wilson CJ, Cao Y, Stefani A, Kitai ST: Dopamine receptor subtypes colocalize in rat striatonigral neurons. Proc Natl Acad Sci USA 1992, 89: I0I78-10182.

45. Surmeier DJ, Song W-J, Yan Z: Coordinated expression of dopamine receptors in neostriatal medium spiny neurons. $J$ Neurosci 1996, I6(20):6579-6591.

46. Shetreat ME, Lin L, Wong AC, Rayport S: Visualization of DI dopamine receptors on living nucleus accumbens neurons and their colocalization with D2 receptors. J Neurochem 1996, 66(4): 1475-1482.

47. Wong AC, Shetreat ME, Clarke JO, Rayport S: DI- and D2-like dopamine receptors are colocalized on the presynaptic varicosities of striatal and nucleus accumbens neurons in vitro. Neuroscience 1999, 89(I):221-233.

48. Aizman O, Brismar H, Uhlén $\mathrm{P}$, Zettergren E, Levey Al, Forssberg $\mathrm{H}$, Greengard P, Aperia A: Anatomical and physiological evidence for DI and D2 dopamine receptor colocalization in neostriatal neurons. Nat Neurosci 2000, 3(3):226-230.

49. Waszczak BL, Martin LP, Greif G], Freedman JE: Expression of a dopamine D2 receptor-activated $\mathrm{K}^{+}$channel on identified 
striatopallidal and striatonigral neurons. Proc Natl Acad Sci USA 1998, 95(19): I |440-I I 444.

50. Lee SP, So CH, Rashid AJ, Varghese G, Cheng R, Lanca AJ, O'Dowd BF, George SR: Dopamine DI and D2 receptor Co-activation generates a novel phospholipase C-mediated calcium signal. J Biol Chem 2004, 279(34):3567I-35678.

5I. Falk T, Zhang S, Erbe EL, Sherman SJ: Neurochemical and electrophysiological characteristics of rat striatal neurons in primary culture. J Comp Neurol 2006, 494(2):275-289.

52. Bonci $A$, Hopf FW: The dopamine $D 2$ receptor: new surprises from an old friend. Neuron 2005, 47(3):335.

53. Wu Y, Richard S, Parent A: The organization of the striatal output system: a single-cell juxtacellular labeling study in the rat. Neurosci Res 2000, 38(I):49-62.

54. Parent A, Sato F, Wu Y, Gauthier J, Levesque M, Parent M: Organization of the basal ganglia: the importance of axonal collateralization. Trends Neurosci 2000, 23(10 Suppl):S20-27.

55. Cooper AJ, Stanford IM: Dopamine D2 receptor mediated presynaptic inhibition of striatopallidal GABA $_{A}$ IPSCs in vitro. Neuropharmacology 200I, 41:62-7I.

56. Radnikow G, Misgeld U: Dopamine DI receptors facilitate GABA $_{A}$ synaptic currents in the rat substantia nigra pars reticulata. J Neurosci 1998, 18(6):2009-2016.

57. Cameron DL, Williams JT: Dopamine DI receptors facilitate transmitter release. Nature 1993, 366:344-347.

58. Lindgren N, Usiello A, Goiny M, Haycock J, Erbs E, Greengard P, Hokfelt T, Borrelli E, Fisone G: Distinct roles of dopamine D2L and D2S receptor isoforms in the regulation of protein phosphorylation at presynaptic and postsynaptic sites. Proc Natl Acad Sci USA 2003, 100 (7):4305-4309.

59. Bartlett SE, Enquist J, Hopf FW, Lee JH, Gladher F, Kharazia V, Waldhoer M, Mailliard WS, Armstrong R, Bonci A, Whistler JL: Dopamine responsiveness is regulated by targeted sorting of D2 receptors. Proc Natl Acad Sci USA 2005, 102(32): I I52 I-I I 526.

60. Maurice N, Tkatch T, Meisler M, Sprunger LK, Surmeier DJ: DI/D5 dopamine receptor activation differentially modulates rapidly inactivating and persistent sodium currents in prefrontal cortex pyramidal neurons. J Neurosci 200I, 2 I (7):2268-2277.

61. Maurice N, Mercer J, Chan CS, Hernandez-Lopez S, Held J, Tkatch T, Surmeier DJ: D2 dopamine receptor-mediated modulation of voltage-dependent $\mathrm{Na}^{+}$channels reduces autonomous activity in striatal cholinergic interneurons. I Neurosci 2004, 24(46): 10289-10301.

62. Bacskai BJ, Hochner B, Mahaut-Smith M, Adams SR, Kaang BK, Kandel $E R$, Tsien RY: Spatially resolved dynamics of CAMP and protein kinase A subunits in Aplysia sensory neurons. Science 1993, 260(5 I05):222-226.

63. Conti M, Richter W, Mehats C, Livera G, Park JY, Jin C: Cyclic AMP. specific PDE4 phosphodiesterases as critical components of cyclic AMP signaling. J Biol Chem 2003, 278(8):5493-5496.

64. Zaccolo M, Magalhaes P, Pozzan T: Compartmentalisation of cAMP and $\mathrm{Ca}^{2+}$ signals. Curr Opin Cell Biol 2002, I4(2): I60-166.

65. Rich TC, Fagan KA, Tse TE, Schaack J, Cooper DM, Karpen JW: A uniform extracellular stimulus triggers distinct CAMP signals in different compartments of a simple cell. Proc Natl Acad Sci USA 200I, 98(23): I3049-13054.

66. Rich TC, Fagan KA, Nakata H, Schaack J, Cooper DM, Karpen JW: Cyclic nucleotide-gated channels colocalize with adenylyl cyclase in regions of restricted cAMP diffusion. J Gen Physiol 2000, II6(2): 147-161.

67. Verkman AS: Solute and macromolecule diffusion in cellular aqueous compartments. Trends Biochem Sci 2002, 27(I):27-33.

68. Davare MA, Avdonin V, Hall DD, Peden EM, Burette A, Weinberg RJ, Horne MC, Hoshi T, Hell JW: A $\beta 2$ adrenergic receptor signaling complex assembled with the $\mathrm{Ca}^{2+}$ channel Cavl.2. Science 200I, 293(5527):98-101.

69. Olson PA, Tkatch T, Hernandez-Lopez S, Ulrich S, Ilijic E, Mugnaini E, Zhang H, Bezprozvanny I, Surmeier DJ: G-protein-coupled receptor modulation of striatal CaVI.3 L-type $\mathrm{Ca}^{2+}$ channels is dependent on a Shank-binding domain. J Neurosci 2005, 25(5): 1050-1062.

70. Zhang H, Maximov A, Fu Y, Xu F, Tang TS, Tkatch T, Surmeier DJ, Bezprozvanny I: Association of CaVI.3 L-type calcium channels with Shank. J Neurosci 2005, 25(5): 1037-1049.
7I. Hoogland TM, Saggau P: Facilitation of L-type $\mathbf{C a}^{2+}$ channels in dendritic spines by activation of $\beta 2$ adrenergic receptors. J Neurosci 2004, 24(39):84I6-8427.

72. Tecuapetla F, Carrillo-Reid L, Guzman JN, Galarraga E, Bargas ]: Different inhibitory inputs onto neostriatal projection neurons as revealed by field stimulation. I Neurophysiol 2005, 93(2): III9- II 26.

73. Salgado H, Tecuapetla F, Perez-Rosello T, Perez-Burgos A, PerezGarci E, Galarraga E, Bargas J: A reconfiguration of $\mathbf{C a V 2} \mathbf{C a}^{2+}$ channels current and its dopaminergic D2 modulation in developing neostriatal neurons. I Neurophysiol 2005, 94(2):377|-3787.

74. Schneggenburger R, Neher E: Presynaptic calcium and control of vesicle fusion. Curr Opin Neurobiol 2005, 15(3):266-274.

75. Wolfel M, Schneggenburger R: Presynaptic capacitance measurements and $\mathrm{Ca}^{2+}$ uncaging reveal submillisecond exocytosis kinetics and characterize the $\mathrm{Ca}^{2+}$ sensitivity of vesicle pool depletion at a fast CNS synapse. I Neurosci 2003, 23(18):7059-7068.

76. Graybiel AM: The basal ganglia and chunking of action repertoires. Neurobiol Learn Mem 1998, 70( I-2):1 19-136.

77. PulseControl 5.0 [http://chroma.med.miami.edu/cap]

78. Mainen ZF, Maletic-Savatic M, Shi SH, Hayashi Y, Malinow R, Svoboda $\mathrm{K}$ : Two-photon imaging in living brain slices. Methods 1999, I 8(2):23I-239. 18I

79. Yasuda R, Nimchinsky EA, Scheuss V, Pologruto TA, Oertner TG, Sabatini BL, Svoboda K: Imaging calcium concentration dynamics in small neuronal compartments. SCi STKE 2004, 2004(2 I9):15.

80. Image] [http://rsb.info.nih.gov/ii/]
Publish with Bio Med Central and every scientist can read your work free of charge

"BioMed Central will be the most significant development for disseminating the results of biomedical research in our lifetime. "

Sir Paul Nurse, Cancer Research UK

Your research papers will be:

- available free of charge to the entire biomedical community

- peer reviewed and published immediately upon acceptance

- cited in PubMed and archived on PubMed Central

- yours - you keep the copyright
BiolMedcentral 